\title{
BBS9 Gene
}

National Cancer Institute

\section{Source}

National Cancer Institute. BBS9 Gene. NCI Thesaurus. Code C114660.

This gene plays a role in ciliogenesis. 